\title{
PENGARUH DENSITAS ARUS TERHADAP PERILAKU RETAK BETON BERTULANG YANG MENGALAMI KOROSI TULANGAN
}

\author{
Zahra Amalia $^{1)}$, Taufiq Saidi' ${ }^{2)}$, Teuku Budi Aulia ${ }^{3)}$, Mahlii $^{4)}$ \\ ${ }^{1,2,3,4)}$ Jurusan Teknik Sipil, Fakultas Teknik, Universitas Syiah Kuala \\ Jl. Tgk. Syeh Abdul Rauf No. 7, Darussalam Banda Aceh 23111 \\ Email:zahra.amalia@unsyiah.ac.id ${ }^{1)}$,taufiq_saidi@unsyiah.ac.id ${ }^{2}$, \\ aulia@unsyiah.ac.id ${ }^{3)}$.mahlilciv05@unsyiah.ac.id ${ }^{4)}$
}

DOI: http://dx.doi.org/10.29103/tj.v11i2.507

(Received: March 2021 / Revised: July 2021 / Accepted: August 2021)

\begin{abstract}
Abstrak
Korosi pada struktur beton betulang dapat mengurangi kinerja struktur dan umur layannya karena volume tulangan yang berkurang. Besarnya jumlah korosi yang dipengaruhi oleh laju korosi dapat digambarkan melalui besarnya densitas arus yang terjadi. Jumlah korosi yang terjadi mempengaruhi perilaku retak pada beton bertulang, oleh karen itu, pada studi ini dilakukan uji eksperimental untuk mengevaluasi pengaruh densitas arus terhadap perilaku retak permukaan beton dari struktur beton bertulang yang mengalami korosi tulangan. Pengujian dilakukan dengan mengaplikasikan variasi densitas arus yaitu $900 \mu \mathrm{A} / \mathrm{cm}^{2}, 500 \mu \mathrm{A} / \mathrm{cm}^{2}, 200 \mu \mathrm{A} / \mathrm{cm}^{2}$ and $100 \mu \mathrm{A} / \mathrm{cm}^{2}$ pada pengujian korosi secara elektrik menggunakan larutan $\mathrm{NaCl}$ sebagai elektrolit untuk menghasilkan ion $\mathrm{Cl}^{-}$. Benda uji yang digunakan adalah balok dengan luas penampang 150x150 $\mathrm{mm}^{2}$ dan panjang benda uji $300 \mathrm{~mm}$. Tulangan baja diameter $19 \mathrm{~mm}$ digunakan pada tengah penampang. Hasil pengujian menunjukkan bahwa perilaku retak dari beton bertulang yang mengalami korosi pada tulangannya memiliki kurva yang bilinear. Selain itu, hasil pengujian menunjukkan bahwa densitas arus yang rendah memiliki kecepatan retak permukaan beton yang lebih tinggi jika dibandingkan dengan benda uji dengan menggunakan densitas arus yang tinggi.
\end{abstract}

Kata kunci: korosi, beton bertulang, produk korosi, retak, densitas arus

\begin{abstract}
Corrosion in reinforced concrete structure can reduce structure performance and its service life due to rebar mass loss. Corrosion amount influenced by corrosion rate can be figured out by using current density. Corrosion amount influences the crack behavior of reinforced concrete, therefore, in this study, experimental study was performed to evaluate the effect of current density to surface concrete cracking behavior of corroded reinforced concrete structure. Accelerated corrosion test tests were conducted with various current density. It was $900 \mu \mathrm{A} / \mathrm{cm} 2,500 \mu \mathrm{A} / \mathrm{cm} 2,200$ $\mu \mathrm{A} / \mathrm{cm} 2$ and $100 \mu \mathrm{A} / \mathrm{cm} 2 . \mathrm{NaCl}$ solution was used as electrolyte to produce ion $\mathrm{Cl}^{-}$. The specimens were beam with cross section area $150 \times 150 \mathrm{~mm}^{2}$ and $300 \mathrm{~mm}$ in length. Rebar with diameter $19 \mathrm{~mm}$ was applied in the center of specimen. The results showed that cracking behavior of corroded rebar has bilinear curve that shows the effect of corrosion products movement through cracks. Furthermore, lower corrosion rate has higher cracking speed than higher corrosion rate.
\end{abstract}

Keywords: corrosion, reinforced concrete, corrosion products, cracking, current density 


\section{Latar Belakang}

Kerusakan struktur beton bertulang yang disebabkan oleh korosi pada tulangan baja dapat mempengaruhi kinerja strukturalnya. Terbentuknya produk korosi dapat memberikan ekspansi di sekitaran beton dan akan menyebabkan keretakan. Tingginya korosi pada tulangan juga akan mengurangi luasan tulangan dan mengganggu kemampuan layan dari struktur tersebut. Selain itu, lepasnya beton dari struktur (concrete spalling) juga dapat terjadi karena akumulasi keretakan yang diakibatkan oleh meningkatnya jumlah korosi. Hubungan dari perkembangan keretakan terhadap jumlah korosi sangat penting diketahui untuk menghitung tingkatan korosi dan memprediksi sisa layan dari kerusakan struktur tersebut (Alonso et al., 1998). Menurut standard (JSCE, 2002), umur layanan dari beton bertulang yang mengalami korosi terbagi menjadi empat bagian. Tahap pertama merupakan tahap awal (initial stage) saat ion klorida masuk ke dalam beton. Korosi menyebar ketika rembesan ion klorida mulai mencapai konsentrasi kritis sampai terjadinya retakan. Pada tahap percepatan (acceleration stage), retakan menjadi lebih lebar dan luas penampang tulangan mulai berkurang. Retakan menjadi lebih parah dan selimut beton dapat terlepas dari struktur terjadi pada tahap kerusakan (deterioration stage). Hal ini menunjukkan bahwa tingkatan kerusakan berangsur-angsur meningkat seiring bertambahnya waktu.

Umur layan dari struktur beton bertulang pada lingkungan korosif perlu terus terjaga dengan cara dilakukannya pemeliharaan yang baik, oleh karena itu, perkiraan waktu untuk tingkat kerusakan tertentu dari struktur yang mengalami korosi secara alami merupakan suatu aspek penting dalam melakukan perbaikan dan rehabilitasi. Sehingga proses retaknya permukaan beton bertulang yang sangat bergantung pada waktu akibat korosi tulangan perlu dievaluasi, namun, kurangnya informasi dan data mengenai perilaku retak akibat korosi masih sangat terbatas. Waktu korosi pada beton bertulang dapat dikaitkan dengan densitas arus yang terjadi atau yang bekerja pada proses korosi tersebut, selanjutnya, melalui densitas arus juga dapat diprediksi laju korosi yang terjadi.

Beberapa penelitian telah dilakukan untuk mengetahui penyebab awal keretakan (Alonso dkk., 1998; Liu, Y dan Weyers, R. W, 1998; Mullard, J. A dan Mark G. S, 2011), dan perambatan keretakan (Andrade dkk., 1993; El Maaddawy dan Soudki, 2003; Tran dkk., 2011). Dalam penelitian (Andrade et al., 1993) dan (El Maaddawy dan Soudki, 2003) menyebutkan bahwa retak awal dan perambatan keretakan yang terjadi bergantung pada laju korosinya. Pernyataan ini didukung oleh (Takaya, S dkk., 2013) yang menegaskan bahwa morfologi produk korosi yang terbentuk bergantung pada lajunya. Korosi total yang terdiri dari fase padat dan cair berkontribusi pada inisiasi dan perambatan retak. (Malumbela, G dkk., 2012) juga telah melalukan penelitian tentang morfologi produk korosi yang mempengaruhi besarnya rasio ekspansi volume, namun informasi mengenai perilaku retak permukaan beton akibat besarnya laju korosi masih belum sempurna dan perlu untuk dikaji kembali agar informasi tersebut dapat menjadi acuan dalam pembuatan model simulasi. Laju korosi itu sendiri berhubungan dengan densitas arus yang terjadi, oleh karena itu, artikel ini bertujuan untuk mengevaluasi pengaruh densitas arus terhadap perilaku retak permukaan beton dari struktur beton bertulang yang mengalami korosi tulangan. Signifikansi penelitian ini diharapkan dapat memberikan informasi tambahan pada pembuatan model perilaku retak beton 
bertulang akibat korosi tulangan. Secara praktikal, diharapkan nantinya dapat memberikan kontribusi untuk memprediksi besarnya jumlah korosi melalui lebar retak permukaan beton untuk membantu evaluasi pada proses perawatan struktur secara berkala.

\section{Metode Penelitian}

\subsection{Parameter pengujian}

Pada studi ini besarnya nilai densitas arus yang diaplikasikan menjadi parameter pengujian. Tabel 1 menunjukkan parameter pengujian yang digunakan. Lima buah benda uji disiapkan untuk masing-masing parameter. Lebarnya retak permukaan beton yang ingin dicapai menjadi kontrol dalam waktu pengujian. Lebar retak permukaan yang ingin dicapai ditentukan mulai dari lebar retak yang tampak secara visual $(0.15 \mathrm{~mm})$ kemudian meningkat agar dapat diperoleh hubungan lebar retak dan jumlah korosinya.

Tabel 1 Parameter pengujian

\begin{tabular}{ccc}
\hline No. Seri & $\begin{array}{c}\text { Densitas arus } \\
\left(\mu \mathrm{A} / \mathrm{cm}^{2}\right)\end{array}$ & $\begin{array}{c}\text { Lebar retak permukaan beton } \\
\text { yang dicapai }(\mathrm{mm})\end{array}$ \\
\hline 1 & 900 & \\
\hline 2 & 500 & $0.15 ; 0.30 ; 0.50 ; 1.00 ; 1.50$ \\
\hline 3 & 200 & \\
\hline 4 & 100 & \\
\hline
\end{tabular}

\subsection{Benda Uji dan Material}

Benda uji yang digunakan dalam studi eksperimental ini adalah prisma yang memiliki luas penampang 150x150mm dan lebar $300 \mathrm{~mm}$. tulangan baja ulir berdiameter $19 \mathrm{~mm}$ digunakan dengan posisi perletakan seperti yang terlihat pada Gambar 1. Dua crack widh gauge diaplikasikan pada permukaan benda uji untuk merekam lebar retak yang terjadi. Benda uji dipotong setelah selesai diuji untuk dilihat propagasi retak dalam yang terjadi.

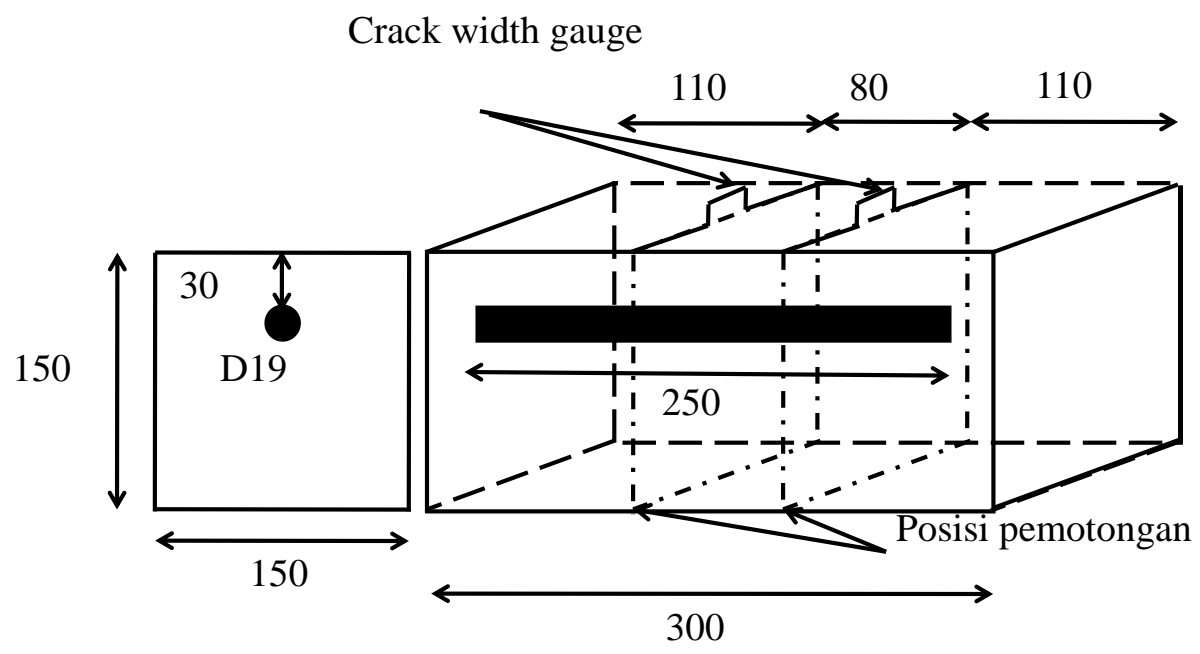

Gambar 1 Detail benda uji 
Campuran beton yang digunakan menggunakan jenis early strength Portland Cement dengan maksimum ukuran butiran aggregate $20 \mathrm{~mm}$. Proporsi campuran beton disajikan pada Tabel 2. Benda uji dirawat dengan cara dibungkus seluruh permukaannya menggunakan plastik dan diletakkan di ruang kedap udara bertemperatur $20^{\circ} \mathrm{C}$ selama 7 hari dan sebelum dimulai pengujian korosi, pengujian kuat tekan dan kuat tarik belah beton dilakukan. Nilai modulus elastisitas beton, kuat tekan dan kuat tarik belah yang diperoleh adalah 27.62 GPa, 37.25 MPa dan 2.70 MPa secara berurutan.

Tabel 2. Proporsi campuran beton

\begin{tabular}{cccccc}
\hline \multirow{2}{*}{ FAS } & \multicolumn{5}{c}{ Unit $\left(\mathrm{kg} / \mathrm{m}^{3}\right)$} \\
\cline { 2 - 6 } & Air & Semen & Agregat Kasar & Pasir Halus & AE*(liter/m3) \\
\hline 0,58 & 166 & 282 & 1225 & 819 & 1.18 \\
\hline
\end{tabular}

*air entrance

\subsection{Pengujian Korosi}

Benda uji direndam dalam air larutan $3 \% \mathrm{NaCl}$ pada wadah seperti yang terlihat pada Gambar 2a. Larutan $\mathrm{NaCl}$ berfungsi sebagai elektrolit untuk menghasilkan ion $\mathrm{Cl}^{-}$pada pengujian korosi secara elektrik. Tulangan disambungkan pada direct-current $(D C)$ power source dan pelat kuningan yang juga direndam dalam larutan $\mathrm{NaCl}$. Tulangan dan pelat kuningan merupakan anoda dan katoda pada pengujian korosi secara berurutan. Selama pengujian, densitas arus yang diinput adalah konstan. Keempat seri parameter diuji secara bersamaan dengan rangkaian sambungan seperti yang terlihat pada Gambar 2b, sehingga aliran arus nya adalah sama.

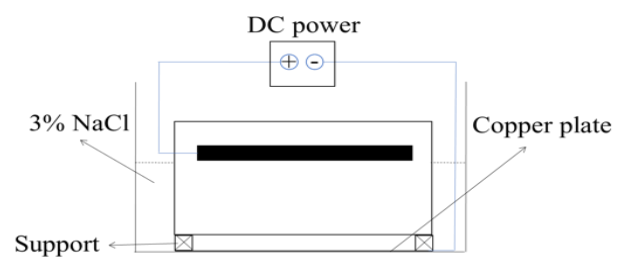

(a) Benda uii tunggal

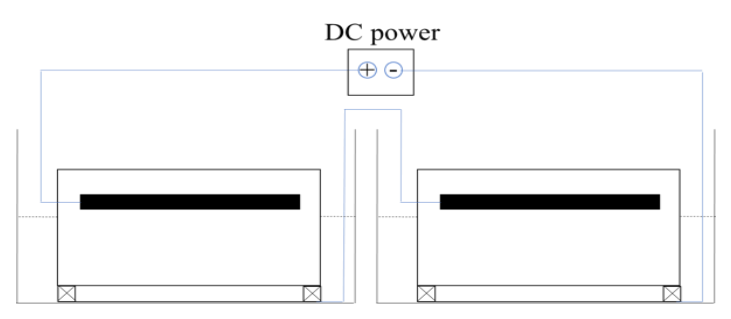

(b) Benda uji ganda

Gambar 2. Rangkaian pengujian korosi

\subsection{Pengukuran Jumlah Korosi dan Lebar Retak Permukaan}

Benda uji direndam dalam air larutan $3 \% \mathrm{NaCl}$ pada wadah seperti yang terlihat pada Gambar 2a. Larutan $\mathrm{NaCl}$ berfungsi sebagai elektrolit untuk menghasilkan ion $\mathrm{Cl}$ - pada pengujian korosi secara elektrik. Tulangan 
disambungkan pada direct-current (DC) power source dan pelat kuningan yang juga direndam dalam larutan $\mathrm{NaCl}$. Tulangan dan pelat kuningan merupakan anoda dan katoda pada pengujian korosi secara berurutan. Selama pengujian, densitas arus yang diinput adalah konstan. Keempat seri parameter diuji secara bersamaan dengan rangkaian sambungan seperti yang terlihat pada Gambar 3, sehingga aliran arus nya adalah sama. Korosi terjadi karena adanya proses elektromekanis pada beton bertulang. Lapisan pasif pada tulangan baja mengalami kerusakan saat konsentrasi ion Cl- dalam beton mencapai nilai ambang batas. Ketika korosi dimulai pada tulangan, area yang sebenarnya terkorosi adalah anodik, sedangkan area non-korosi yang berdekatan di sekitar lokasi korosi adalah katodik. Elektron mengalir dari daerah anodik ke daerah katodik yang berasosiasi dengan ion $\mathrm{OH}$ menghasilkan arus listrik dan membentuk $\mathrm{Fe}(\mathrm{OH})_{2}$. Produk korosi berwarna merah khas dapat terbentuk ketika bereaksi dengan oksigen dan air yang masuk dalam beton. Korosi pada tulangan menyebabkan hilangnya sebagian massa tulangan. Perbandingan kehilangan massa tulangan terhadap luas permukaan basah tulangan disebut jumlah korosi.

Jumlah korosi diukur pada saat lebar retak permukaan yang telah disebutkan pada Tabel 1 tercapai. Perhitungan jumlah korosi tulangan, $\mathrm{Wr}\left(\mathrm{mg} / \mathrm{cm}^{2}\right)$ dapat dihitung dengan perbandingan kehilangan massa tulangan (mg) terhadap luas permukaan basah tulangan $\left(\mathrm{cm}^{2}\right)$ :

$$
W_{r}=\frac{\Delta M}{S_{w e t}}=\frac{M_{0}-M_{1}}{\pi d L}
$$

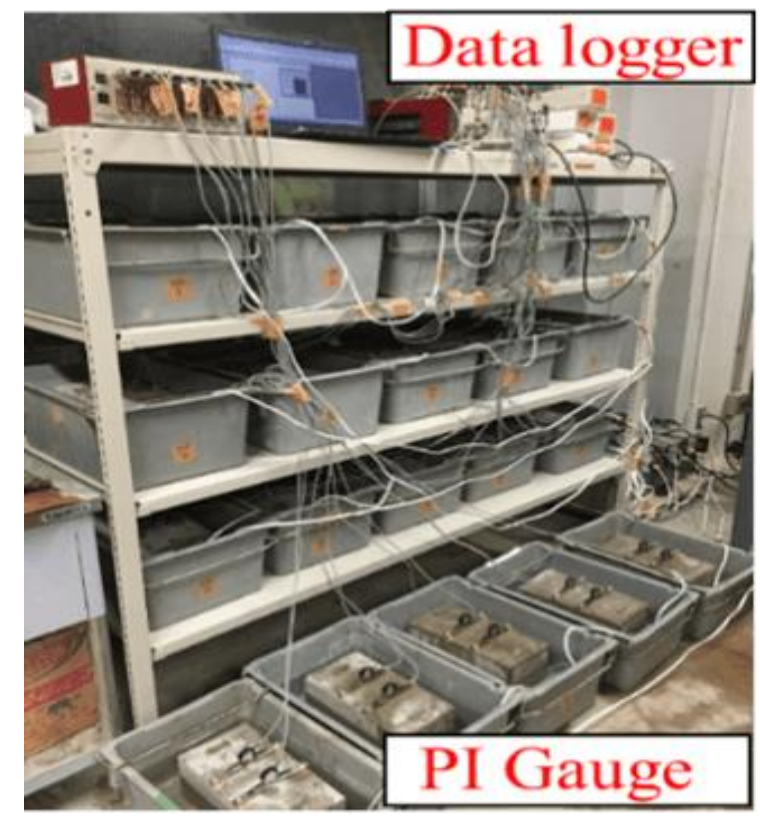

Gambar 3. Pengujian korosi secara elektrik di laboratorium

Jumlah korosi dihitung berdasarkan berat massa yang hilang pada tulangan $(\triangle M)$. Saat lebar retak permukaan yang didesain tercapai, benda uji dipotong menjadi tiga bagian dan tulangan diambil dari beton. Tulangan yang telah mengalami korosi direndam dalam larutan 10\% ammonium citrate selama 24 jam dan produk korosi dihilangkan dengan menggunakan sikat kawat. Berat tulangan 
yang telah mengalami korosi kemudian ditimbang untuk mengetahui sisa berat tulangan $\left(M_{1}\right)$ dan dibandingkan dengan berat actual tulangan sebelum dilakukan pengujian $\left(M_{0}\right)$. Massa yang hilang dari tulangan adalah perbedaan diantaranya $\left(M_{0}-M_{1}\right)$.

Lebar retak permukaan diukur selama pengujian korosi berlangsung dengan menggunakan dua strain gauges tipe displacement transducer (PI gauge). PI gauge direkatkan pada permukaan atas benda uji dan datanya direkam dengan menggunakan a data logger seperti yang terlihat pada Gambar 3. Tulangan yang disambungkan pada direct-current $(D C)$ power source dan pelat kuningan yang direndam dalam larutan $\mathrm{NaCl}$ akan menghasilkan ion $\mathrm{Cl}^{-}$yang dapat menyebabkan tulangan menjadi korosi dan menimbulkan retak beton.

\section{Hasil dan Pembahasan}

\subsection{Hubungan aliran arus terhadap retak permukaan}

Gambar 4 menunjukkan hubungan antara lebar retak permukaan dengan aliran arus. Hasil ini diperoleh langsung melalui PI gauges yang telah ditempelkan pada benda uji. Melalui Gambar 4, dapat terlihat bahwa densitas arus yang tinggi membutuhkan waktu yang relative lebih cepat untuk dapat menginisiasi retak dan memiliki laju propagasi retak yang lambat jika dibandingkan dengan benda uji dengan densitas arus yang lebih rendah. Dapat dilihat pada seri $900 \mu \mathrm{A} / \mathrm{cm}^{2}, 125$ ampere hours dibutuhkan untuk mencapai retak permukaan $1 \mathrm{~mm}$, sedangkan pada seri $100 \mu \mathrm{A} / \mathrm{cm}^{2}$ hanya memerlukan laju sekitar 37.5 ampere hours.

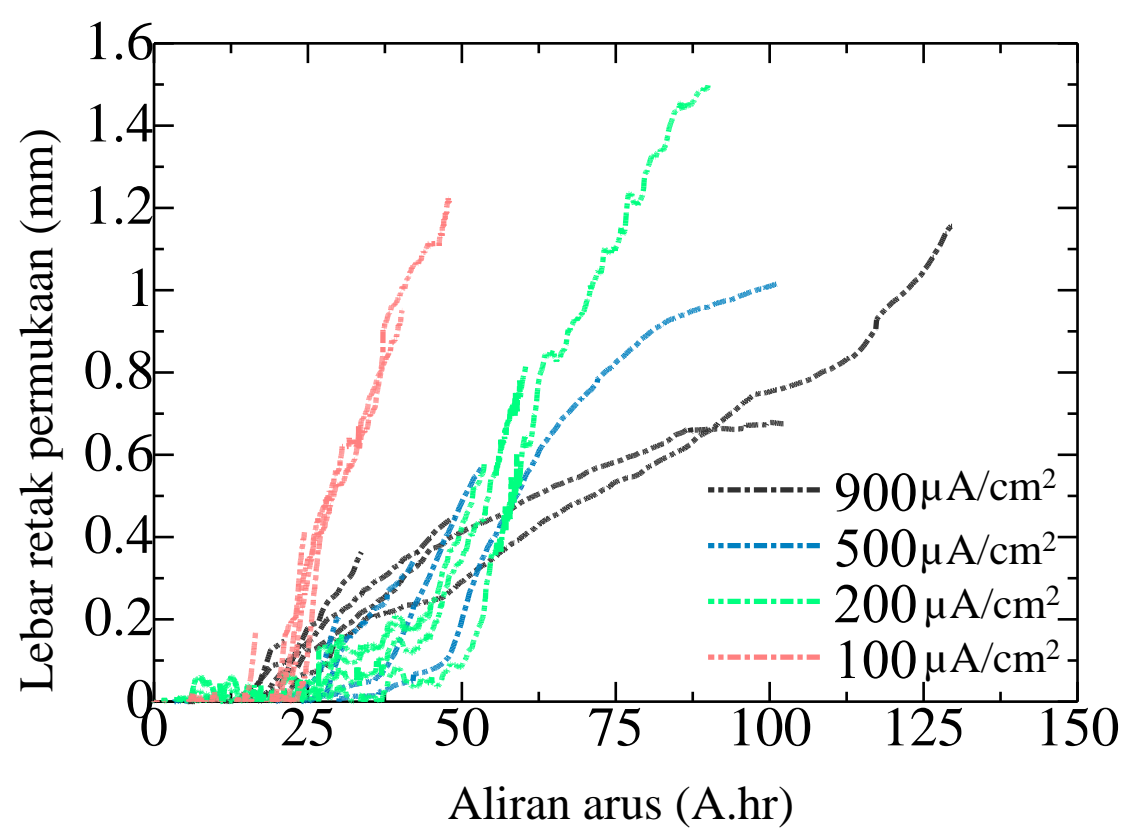

Gambar 4 Hubungan antara lebar retak permukaan dengan aliran arus

\subsection{Hubungan lebar retak permukaan dengan jumlah korosi}

Jumlah korosi dihitung berdasarkan massa yang hilang pada tulangan yang berhubungan langsung dengan aliran arus berdasarkan hukum faraday. Gambar 5 menunjukkan hubungan antara kehilangan massa tulangan dan aliran arus. Pada gambar 5, nilai dari setiap titik menunjukkan seberapa lebar retakan yang dicapai. 
Garis linear $\mathrm{N}=1$ merupakan jumlah hilangnya massa secara teoritis dihitung dengan Hukum Faraday dengan efisiensi korosi 100\%). Pada seri $900 \mu \mathrm{A} / \mathrm{cm}^{2}, 500$ $\mu \mathrm{A} / \mathrm{cm}^{2}$ dan $200 \mu \mathrm{A} / \mathrm{cm}^{2}$, terdapat bilinear tren pada propagasi kehilangan massa tulangan berdasarkan aliran arusnya. Pada tahap awal Gambar 5a, Gambar 5b dan Gambar 5c memperlihatkan bahwa kehilangan massa tulangan aktual lebih rendah daripada kehilangan massa teoritis, namun memiliki tingkat kemiringan yang berbeda karena adanya perbedaan densitas arus.

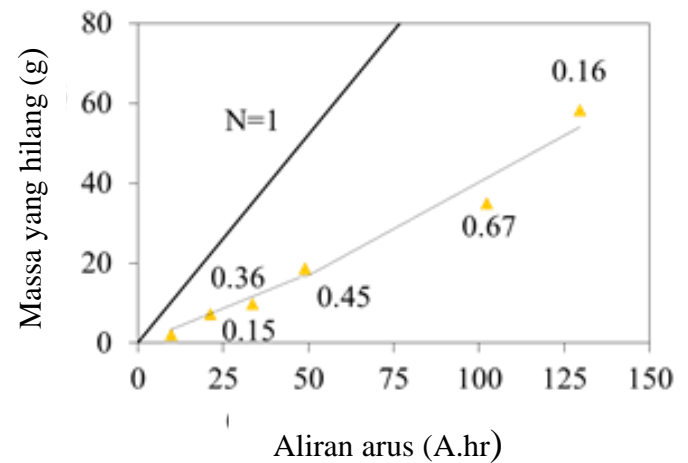

(a) Seri $900 \mu \mathrm{A} / \mathrm{cm}^{2}$

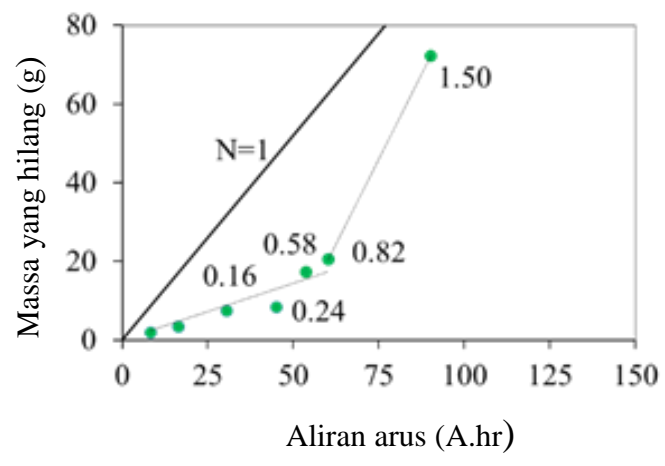

(c) Seri $200 \mu \mathrm{A} / \mathrm{cm}^{2}$

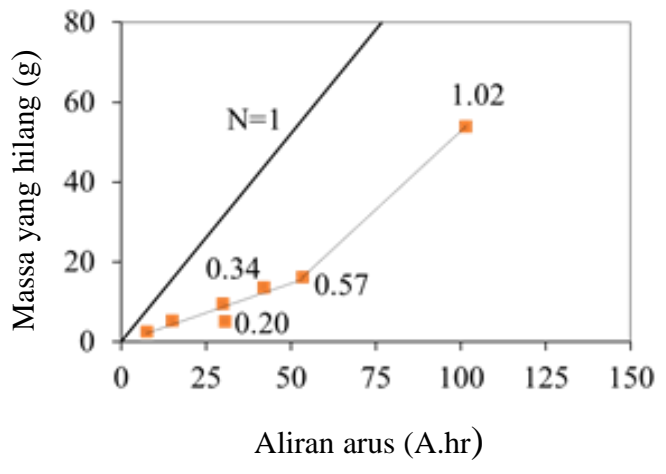

(b) Seri $500 \mu \mathrm{A} / \mathrm{cm}^{2}$

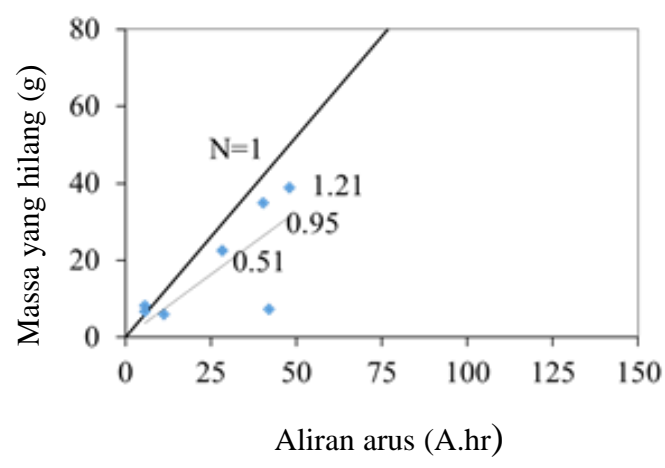

(d) Seri $100 \mu \mathrm{A} / \mathrm{cm}^{2}$

Gambar 5 Hubungan antara kehilangan massa tulangan dan aliran arus

Seiring melebarnya retak, efisiensipun meningkat namun tidak secara konstan sehingga kemiringan menjadi lebih tinggi setelah tingkat korosi tententu dicapai. Sebaliknya, untuk $100 \mu \mathrm{A} / \mathrm{cm}^{2}$ pada Gambar 5d, terjadinya hubungan linier yang dapat dilihat dari efisiensi arus yang meningkat secara konstan dalam waktu tersebut. Laju hilangnya massa tulangan dalam jangka waktu tertentu dapat dikembangkan melalui hubungan antara massa tulangan dengan aliran arus. Berdasarkan data pengujian yang ditunjukkan pada Gambar 5, persamaan empiris untuk menghitung kehilangan massa tulangan dapat diperoleh dan dinyatakan dalam persamaan 2. Persamaan untuk densitas arus $900 \mu \mathrm{A} / \mathrm{cm}^{2}$ sesuai dengan persamaan yang diperoleh oleh Tran (2012).

$$
900 \mu \mathrm{A} / \mathrm{cm}^{2} \begin{cases}\Delta M=0.235 I t, & \text { It }<66 A . h r \\ \Delta M=0.617 I t-25.305, & \text { It }>66 A . h r\end{cases}
$$




$$
\begin{aligned}
& 500 \mu \mathrm{A} / \mathrm{cm}^{2} \begin{cases}\Delta M=0.292 I t, & I t<53 A . h r \\
\Delta M=0.784 I t-25.790, & \text { It }>53 A . h r\end{cases} \\
& 200 \mu \mathrm{A} / \mathrm{cm}^{2} \begin{cases}\Delta M=0.288 I t, & \text { It }<61 A . h r \\
\Delta M=1.739 I t-84.499, & \text { It }>61 A . h r\end{cases}
\end{aligned}
$$

$100 \mu \mathrm{A} / \mathrm{cm}^{2}, \Delta M=0.821 I t$

di mana $\Delta \mathrm{M}$, I dan $\mathrm{t}$ masing-masing adalah kehilangan massa tulangan (g), intensitas arus listrik (A) dan waktu pengujian (jam).

\subsection{Retak Permukaan dan Pola Retak Benda Uji}

Lebar retak permukaan diobservasi di semua seri pada beberapa tahap keretakan. Seluruh seri menunjukkan pola retak permukaan yang sama. Retak terjadi sepanjang arah tulangan.

Table 3 Hasil pengujian korosi pada benda uji dengan lebar retak permukaan

\begin{tabular}{|c|c|c|}
\hline \multirow{2}{*}{$\begin{array}{l}\text { Densitas arus } \\
\left(\mu \mathrm{A} / \mathrm{cm}^{2}\right)\end{array}$} & \multicolumn{2}{|c|}{ Lebar retak permukaan $\pm 0.5 \mathrm{~mm}$} \\
\hline & Retak permukaan dan retak dalam & Kondisi korosi tulangan \\
\hline \multicolumn{3}{|l|}{900} \\
\hline \multicolumn{3}{|l|}{500} \\
\hline \multicolumn{3}{|l|}{200} \\
\hline \multicolumn{3}{|l|}{100} \\
\hline & 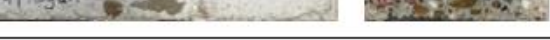 & \\
\hline
\end{tabular}
$0.5 \mathrm{~mm}$

Retak dalam benda uji juga menunjukkan pola yang sama pada keseluruhan seri. Retak diawali dengan retak arah vertikal dan seiring dengan bertambahnya lebar retak pernukaan, maka retak horizontal di kiri dan kanan tulangan terjadi. Tabel 3 menunjukkan retak permukaan, retak dalam benda uji dan kondisi tulangan yang mengalami korosi pada lebar retak permukaan $0.5 \mathrm{~mm}$. Banyak produk korosi yang terlihat pada seri pengujian dengan densitas arus $900 \mu \mathrm{A} / \mathrm{cm}^{2}$ dan $500 \mu \mathrm{A} / \mathrm{cm}^{2}$, sedangkan pada seri $200 \mu \mathrm{A} / \mathrm{cm}^{2}$ dan $100 \mu \mathrm{A} / \mathrm{cm}^{2}$ produk korosi yang timbul lebih 
sedikit. Hasil ini menunjukkan bahwa produk korosi yang dihasilkan pada kasus dengan densitas arus yang tinggi memiliki fase cair yang lebih banyak daripada fase solidnya sebagaimana yang telah diperoleh pada hasil penelitian (Amalia dkk., 2018) secara eksperimental dan numerikal Hasil ini juga didukung oleh penelitian (Takaya, S dkk., 2013; Wong dkk., 2010).

Jenis korosi yang terjadi hampir seluruhnya adalah korosi seragam pada densitas arus yang rendah sedangkan pada densitas arus yang tinggi dapat terlihat timbulnya lubang kecil yang biasa diseebut dengan pitting corrosion, namun hal ini juga dapat terlihat pada benda uji dengan tingkat korosi yang lebih tinggi meskipun menggunakan densitas arus yang rendah. Berdasarkan (National Association of Corrosion Engineers (NACE), 2016), organisasi profesional nirlaba untuk industri pengendalian korosi, pitting corrosion diinisiasi dengan rusaknya lapisan oksidasi yang melindngi tulangan secara lokal (tidak seragam) karena rendahnya konsentrasi oksigen yang terlarut. Semakin tinggi densitas arus nya, laju ingress oksigen ke dalam beton dapt semakin rendah atau tidak mencukupi. Retak diawali muncul pada kedua ujung tulangan. Hal itu dapat terjadi karena selimut beton di sisi samping benda uji lebih kecil dari pada sisi atas (sisi observasi) benda uji. Saat retak terjadi, transport ion $\mathrm{Cl}$ - ion dan air menjadi lebih cepat sehingga mempercepat proses korosi.

\subsection{Pengaruh densitas arus terhadap perilaku retak permukaan beton}

Gambar 6 menunjukkan hubungan antara lebar retak permukaan dan asumsi jumlah korosi. Asumsi ini dihitung berdasarkan Persamaan 2 dan perhitungan jumlah korosi dari Persamaan 1.

Pada tahap awal, dari Gambar 6 dapat dilihat bahwa spesimen dengan densitas arus yang lebih tinggi mengalami retak lebih awal daripada kasus dengan densitas arus rendah. Jumlah korosi yang diperlukan pada saat mulai megalami keretakan pada seri $900 \mu \mathrm{A} / \mathrm{cm}^{2}$ adalah sekitar $25 \mathrm{mg} / \mathrm{cm}^{2}$. Untuk $500 \mu \mathrm{A} / \mathrm{cm}^{2}$ dan $200 \mu \mathrm{A} / \mathrm{cm}^{2}$, nilai besaran korosi yang diperoleh yaitu sekitar $50 \mathrm{mg} / \mathrm{cm}^{2}$. Sedangkan untuk seri $100 \mu \mathrm{A} / \mathrm{cm}^{2}$ terlihat bahwa retakan terjadi pada saat jumlah korosi mencapai $100 \mathrm{mg} / \mathrm{cm}^{2}$. Hal ini sejalan dengan Gambar 4.

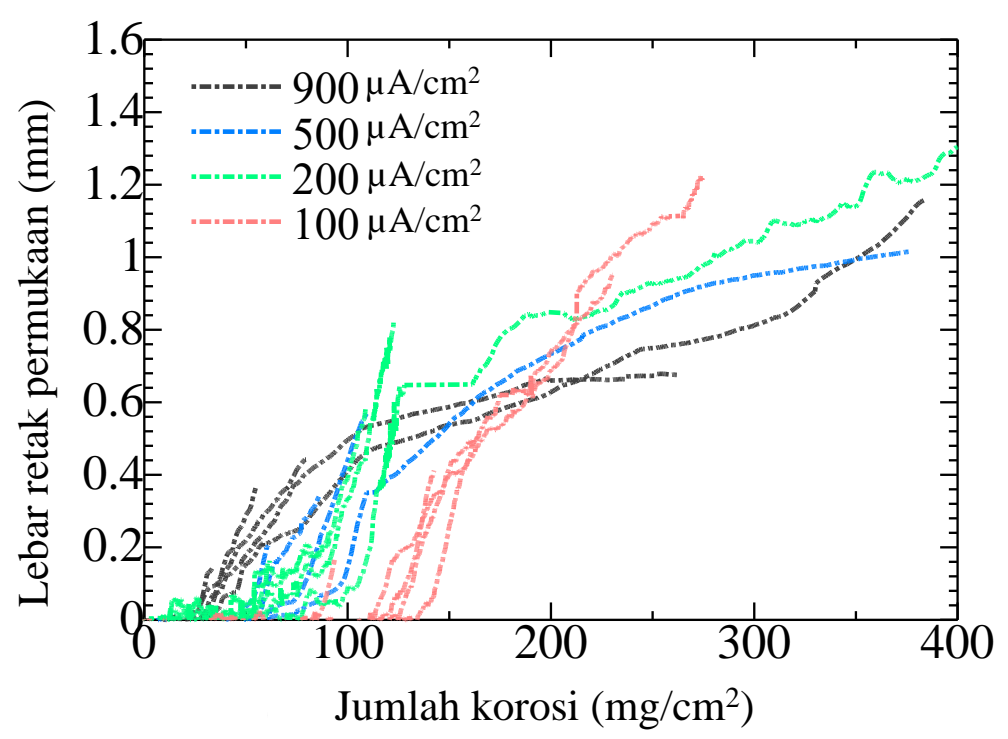

Gambar 6 Hubungan antara lebar retak permukaan dan jumlah korosi 
Densitas arus yang tinggi dapat menginisiasi retak lebih awal namun jumlah korosi yang diperlukan untuk menginisiasi retak tersebut lebih rendah daripada benda uji dengan densitas arus yang rendah. Hasil ini menunjukkan nilai yang berbeda dibandingkan dengan hasil penelitian dari (Alonso dkk., 1998; Andrade dkk., 1993; Caré dan Raharinaivo, 2007). Hasil penelitian mereka menunjukkan bahwa perbedaan titik awal retak korosi pada laju korosi yang berbeda dapat diabaikan, sedangkan dalam penelitian ini perbedaannya terlihat jelas, hal ini dapat disebabkan oleh kekurangan data percobaan yang bergantung pada kualitas beton, porositas pada interface baja dan beton, dan kondisi lingkungan selama pengujian. Pada tahap propagasi retak, spesimen dengan densitas arus tinggi memiliki kecepatan retak yang lebih lambat dibandingkan spesimen dengan densitas arus rendah. Hasil ini sama dengan yang diperoleh (Pedrosa dan Andrade, 2017), kemiringan perkembangan lebar retak awal lebih tinggi untuk laju korosi yang rendah dan lebih kecil untuk laju korosi yang lebih tinggi. Setelah terjadi keretakan, spesimen dengan densitas arus rendah menunjukkan kecepatan perkembangan retak yang lebih besar hingga mencapai nilai tertentu dari lebar retak pada permukaan. Sehingga trend grafik menunjukkan hubungan jumlah korosi dan lebar retak memiliki hubungan bilinear. Dapat dilihat pada seri $200 \mu \mathrm{A} / \mathrm{cm}^{2}$ kemiringan perambatan retak semakin lambat setelah lebar retak permukaan menjadi 0,6 $\mathrm{mm}$. Titik perubahan tren grafik memiliki nilai berbeda diantara setiap seri.

Bentuk kurva bilinear ini sesuai dengan hasil penelitian yang diperoleh (Pedrosa dan Andrade, 2017). Menurut penelitian tersebut, perkembangan lebar retak yang mengalami perlambatan (setelah titik perubahan) dapat dikaitkan dengan efek gabungan dari perilaku pelunakan regangan tarik beton dan pengurangan tekanan akibat gerakan produk korosi. Hasil pengujian menunjukkan keretakan yang terjadi diantara semua seri memiliki perilaku yang berbeda dalam kurun waktu tertentu. Menurut (Pedrosa dan Andrade, 2017), laju korosi yang berbeda terlihat menghasilkan laju pembebanan yang berbeda pula sehingga menyebabkan berbedanya sifat kehancuran efektif beton. Selain itu, perbedaan persentase antara bagian cair dan padat pada produk korosi akibat laju korosi yang berbeda mempengaruhi tekanan ekspansi yang ditimbulkan.

Menurut (Gebreyouhannes dan Maekawa, 2016), produk korosi yang terdiri dari bagian cair dan padat serta penggunaan densitas arus yang tinggi pada uji korosi akan menghasilkan produk korosi yang lebih mudah larut dibandingkan dengan penggunaan densitas arus rendah, hal ini dapat berkontribusi pada proses keretakan beton. Densitas arus yang tinggi dapat menghasilkan produk korosi yang memiliki persentase cairan yang lebih banyak maka lebih mudah untuk bergerak melewati retakan dan mengurangi tekanan, sehingga kecepatan retak menjadi lebih kecil, hal ini dapat dilihat pada Tabel 3, spesimen yang mengalami densitas arus tinggi menghasilkan banyak produk korosi pada permukaan atas spesimen dibandingkan dengan spesimen dengan kerapatan arus rendah yan memiliki lebar retak permukaan yang sama. Sehingga dapat disimpulkan bahwa produk korosi dapat dengan mudah bergerak melalui retakan pada seri kepadatan arus yang lebih tinggi. 


\section{Kesimpulan}

Pada studi ini, benda uji dengan berbagai densitas arus diuji untuk menginvestigasi perilaku retak terhadap waktu. Berdasarkan hasil uji eksperimen yang telah dilakukan, dapat disimpulkan bahwa densitas arus yang tinggi dapat menginisiasi retak permukaan beton lebih cepat dari pada benda uji dengan densitas arus yang rendah, namun jumlah korosi yang diperlukan untuk menginisiasi retak pada benda uji dengan densitas arus rendah lebih tinggi daripada benda uji dengan densitas arus tinggi. Perilaku retak pada beton bertulang yang mengalami korosi memiliki kurva yang bilinear dan menunjukkan adanya pengaruh pergerakan produk korosi melalui retak-retak yang dihasilkan. Selain itu, densitas arus yang rendah memiliki laju keretakan yang lebih tinggi jika dibandingkan dengan densitas arus yang tinggi.

\section{Daftar Kepustakaan}

Alonso, C., Andrade, C., Rodriguez, J., Diez, J.M., 1998. Factors controlling cracking of concrete affected by reinforcement corrosion. Mater. Struct. 31, 435-441. https://doi.org/10.1007/BF02480466

Amalia, Z., Qiao, D., Nakamura, H., Miura, T., Yamamoto, Y., 2018. Development of simulation method of concrete cracking behavior and corrosion products movement due to rebar corrosion. Constr. Build. Mater. 190, 560-572. https://doi.org/10.1016/j.conbuildmat.2018.09.100

Andrade, C., Alonso, C., Molina, F.J., 1993. Cover cracking as a function of bar corrosion: Part I-Experimental test. Mater. Struct. 26, 453-464. https://doi.org/10.1007/BF02472805

Caré, S., Raharinaivo, A., 2007. Influence of impressed current on the initiation of damage in reinforced mortar due to corrosion of embedded steel. Cem. Concr. Res. 37, 1598-1612. https://doi.org/10.1016/j.cemconres.2007.08.022

El Maaddawy, T.A., Soudki, K.A., 2003. Effectiveness of Impressed Current Technique to Simulate Corrosion of Steel Reinforcement in Concrete. J. Mater. Civ. Eng. 15, 41-47. https://doi.org/10.1061/(ASCE)08991561(2003)15:1(41)

Gebreyouhannes, E., Maekawa, K., 2016. Nonlinear Gel Migration in Cracked Concrete and Broken Symmetry of Corrosion Profiles. J. Adv. Concr. Technol. 14, 271-286. https://doi.org/10.3151/jact.14.271

JSCE, 2002. Standard Specification for Concrete Structure Construction. Maruzen, Tokyo.

Liu, Y, Weyers, R. W, 1998. Modeling the Time-to-Corrosion Cracking in Chloride Contaminated Reinforced Concrete Structures. ACI Mater. J. 95. https://doi.org/10.14359/410

Malumbela, G, Moyo, P, Alexander, M, 2012. A Step Towards Standardising Accelerated Corrosion Tests on Laboratory Reinforced Concrete Specimens. J. South Afr. Inst. Civ. Eng. 54, 78-85. 
Mullard Jhon A, Mark G. Stewart, 2011. Corrosion-Induced Cover Cracking: New Test Data and Predictive Models. ACI Struct. J. 108. https://doi.org/10.14359/51664204

National Association of Corrosion Engineers (NACE), 2016. International Measures of Prevention, Application, and Economics of Corrosion Technologies Study, in: NACE International IMPACT.

Pedrosa, F., Andrade, C., 2017. Corrosion induced cracking: Effect of different corrosion rates on crack width evolution. Constr. Build. Mater. 133, 525-533. https://doi.org/10.1016/j.conbuildmat.2016.12.030

Takaya, S, Nakamura, S, Yamamoto, T, Miyagawa, T, 2013. Influence of Steel Corrosion Products in Concrete on Crack Opening Weight Loss of Corrosion. J. JSCE 69, 154-165.

Tran, K.K., Nakamura, H., Kawamura, K., Kunieda, M., 2011. Analysis of crack propagation due to rebar corrosion using RBSM. Cem. Concr. Compos. 33, 906-917. https://doi.org/10.1016/j.cemconcomp.2011.06.001

Wong, H.S., Zhao, Y.X., Karimi, A.R., Buenfeld, N.R., Jin, W.L., 2010. On the penetration of corrosion products from reinforcing steel into concrete due to chloride-induced corrosion. Corros. Sci. 52, 2469-2480. https://doi.org/10.1016/j.corsci.2010.03.025 